\title{
Assessing the Prevalence of Type 2 Diabetes in Patients with Psoriasis Referred to Sina Hospital, Hamadan, Iran
}

\author{
Mohammadreza Sobhan $^{1, *}$ (D), Shima Khosravi², Abbas Moradi ${ }^{3}$ \\ ${ }^{I}$ Assistant Professor, Department of Dermatology, Psoriasis Research Center, Hamadan University of Medical Sciences, \\ Hamadan, Iran \\ ${ }^{2}$ General Practitioner, Hamadan University of Medical Sciences, Hamadan, Iran \\ ${ }^{3}$ Faculty Member, Department of Community Medicine, School of Medicine, Hamadan University of Medical Sciences, \\ Hamadan, Iran \\ * Corresponding Author: Mohammadreza Sobhan, Department of Dermatology, Psoriasis Research Center, Hamadan \\ University of Medical Sciences, Hamadan,Iran.Email: mreza_sobhan@yahoo.com
}

Received: 13.08 .2019 Accepted: 17.11 .2019

\section{How to Cite this Article:} Sobhan M, Khosravi S, Moradi A. Assessing the Prevalence of Type 2 Diabetes in Patients with Psoriasis Referred to Sina Hospital, Hamadan, Iran. Avicenna J Clin Med. 2019; 26(3): 143-150. DOI: $10.29252 /$ ajcm.26.3.143

\section{Abstract}

Background and Objective: Psoriasis is one of the most common skin diseases affecting $2-4 \%$ of the population. Based on the related literature, patients with psoriasis are at increased risk of developing type 2 diabetes. The present study aimed to compare the patients with psoriasis to healthy individuals in terms of prevalence of diabetes.

Materials and Methods: This cross-sectional case-control study was carried out in Sina Hospital, Hamadan, Iran. A total of 35 patients with psoriasis were allocated to the case group and 35 healthy subjects who were comparable in terms of age and gender were assigned to the control group. All participants were examined concerning fasting plasma glucose (FPG) and body mass index. In both groups, the $\mathrm{FPG} \geq 126 \mathrm{mg} / \mathrm{dl}$ indicated diabetes. The collected data were analyzed in SPSS software (version 16.0; SPSS Inc. Chicago, IL). A p-value less than 0.05 was considered statistically significant.

Results: In each group, 19 individuals (54.3\%) were male. Mean age in case group was $43 \pm 11.5$ and in controls was $45.1 \pm 12.8$ ( $p$-value=0.481). The mean Psoriasis Area and Severity Index (PASI) of the patients was $20.6 \pm 12.7$ (1.4 to 49.8 ). The most frequent severity of psoriasis regarding PASI was moderate including 16 patients $(45.7 \%)$. The mean FPG in the patients was $108 \pm 33.6$ and in controls $99.6 \pm 20.5 \mathrm{mg} / \mathrm{dl}(\mathrm{P}=0.755)$. Eight patients $(22.9 \%)$ had diabetes while only 3 healthy controls $(8.6 \%)$ had it $(\mathrm{P}=0.188)$. Multivariate logistic regression analysis demonstrated that psoriasis patients with the same gender, BMI and age have almost 4 - fold increased risk of developing diabetes rather than healthy controls $(\mathrm{P}=0.08)$. As evidenced by the obtained results, eight patients with psoriasis $(22.9 \%)$ suffered from diabetes, whereas only three $(8.6 \%)$ of them had diabetes in the control group $(\mathrm{P}=0.188)$. Multivariate logistic regression analysis demonstrated that patients with psoriasis had almost 4-fold increased risk of developing diabetes, compared to healthy people $(\mathrm{P}=0.08)$.

Conclusion: Based on the findings of the current study, the probable association between type 2 diabetes and psoriasis should be taken into account given hyperglycemia in patients with psoriasis.

Keywords: Diabetes Mellitus Type 2, Psoriasis, Severity of Disease 
do): $10.29252 /$ ajcm. 26.3 .143

\title{
بررسى فراوانى ديابت نوع دو در بيماران يسوريازيس مراجعه كننده به درمانكاه و بخش بوست بيمارستان سيناى همدان
}

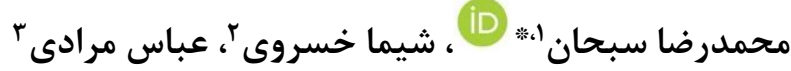 \\ ' استاديار، كروه يوست، دانشكده يزشكى، مركز تحقيقات يسوريازيس، دانشكاه علوم يزشكى همدان، همدان، ايران

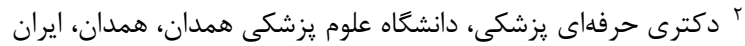

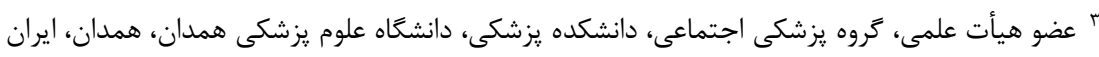
* نويسنده مسئول: محمدرضا سبحان، كروه يوست، دانشكده يزشكى، مركز تحقيقات يسوريازيس، دانشكاه علوم يزشكى همدان، همدان، ايران. ايميل: mreza_sobhan@yahoo.com

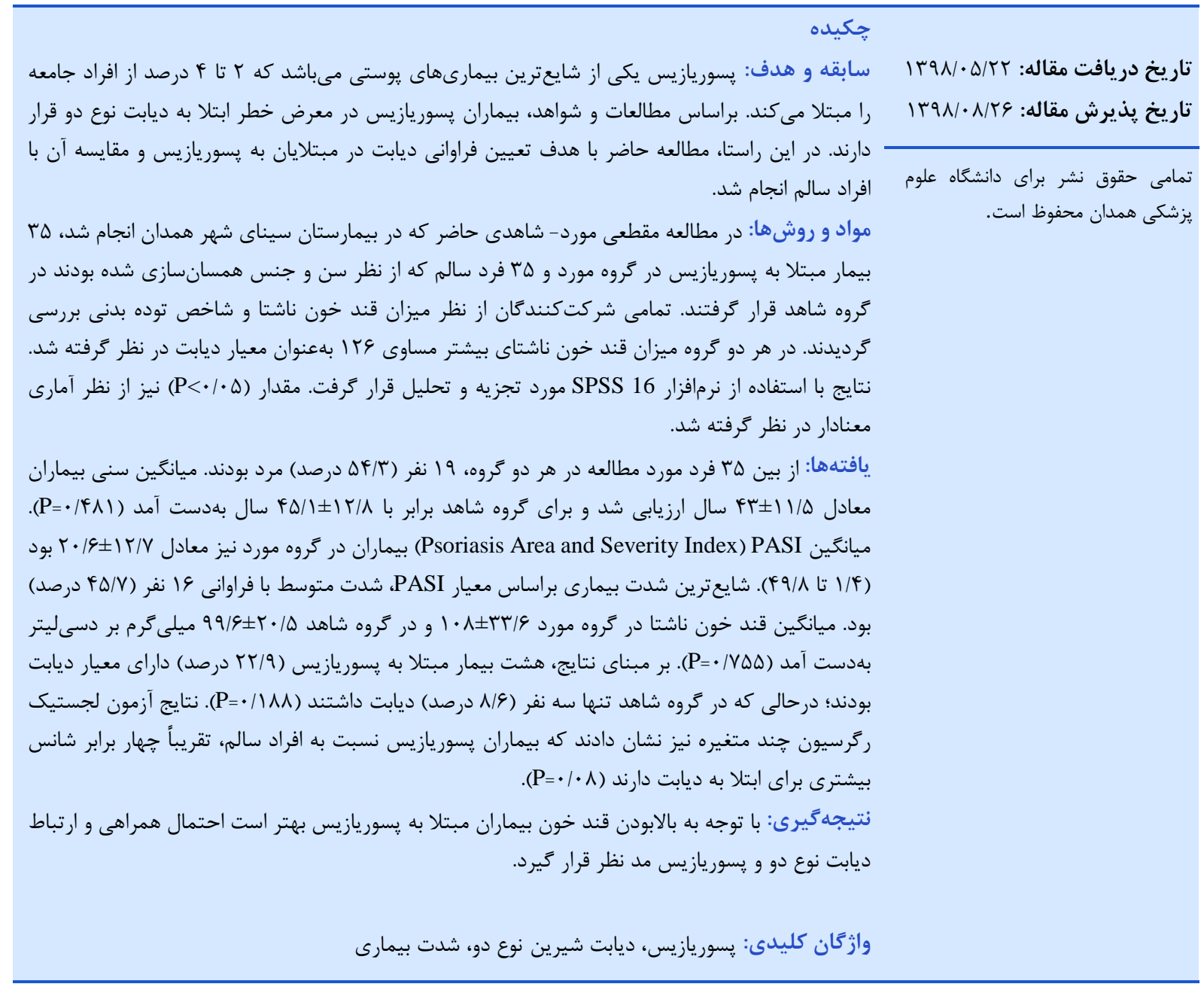

يسوريازيس r درصد از جمعيت عمومى را در سراسر جهان دركير

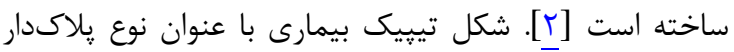

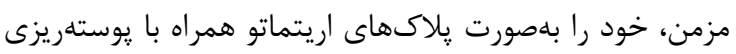

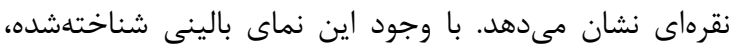

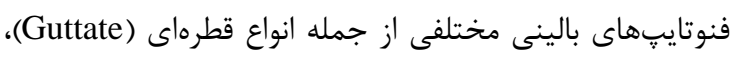

يسوريازيس يك بيمارى يوستى التهابى مزمن با واسطه

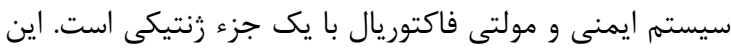

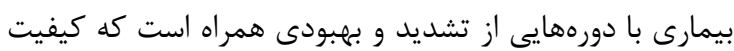

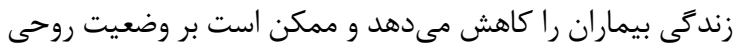

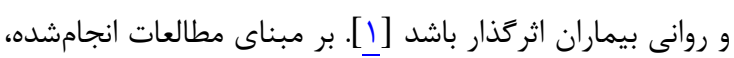


در كشف همراهى و ارتباط آنها كمك كننده باشد. شيوع رو به

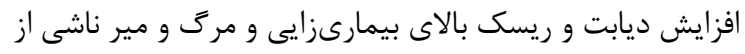

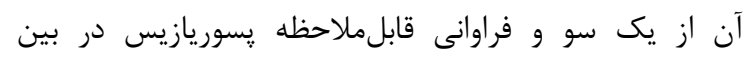

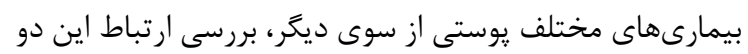

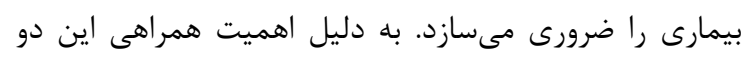

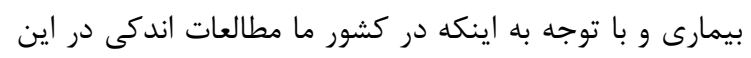

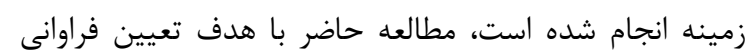

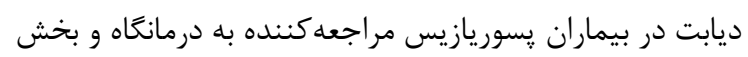

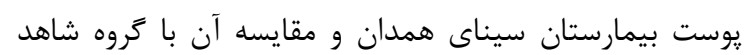

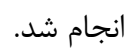

\section{مواد و روشها}

در مطالعه مقطعى مورد- شاهدى حاضر كه طى سالهاى

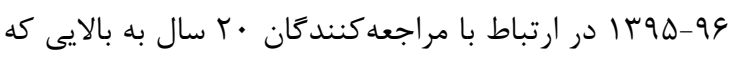

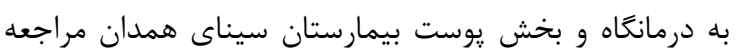

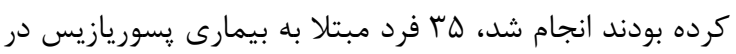

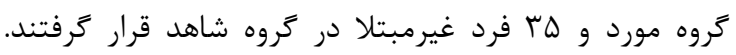

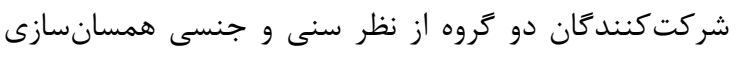

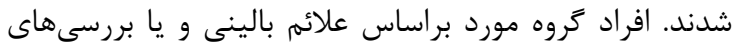

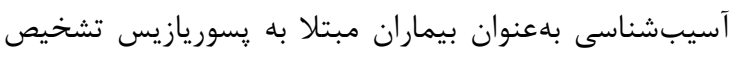

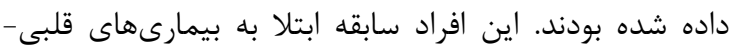

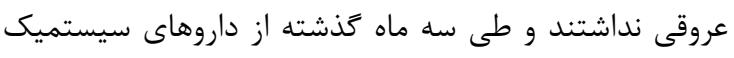
استفاده نكرده بودند. افراد گروه شاهد نيز افراد سالم و همر اهنان

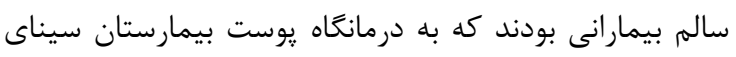

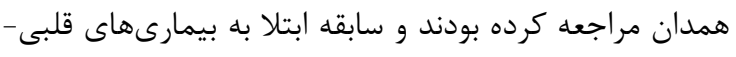

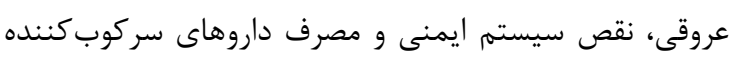

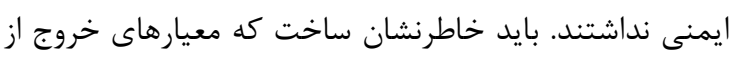

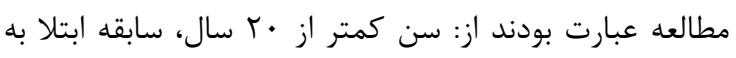

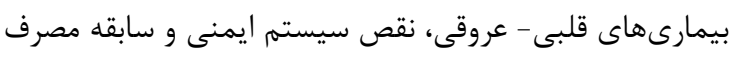

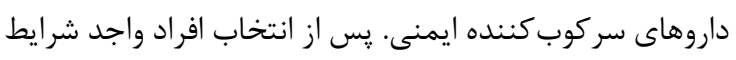

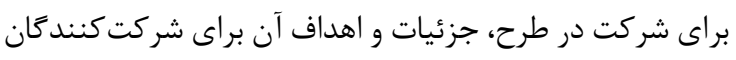

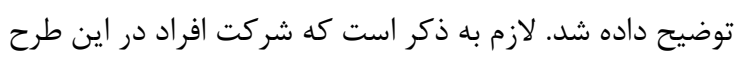

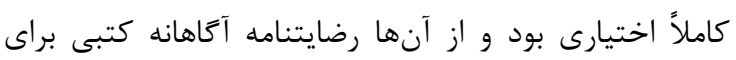
شركت در مطالعه اخذ گرديد. عدم شركت بيماران در مطالعه آنها

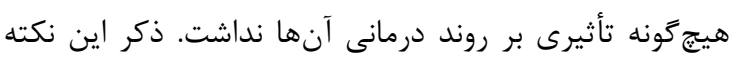

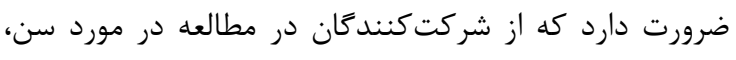

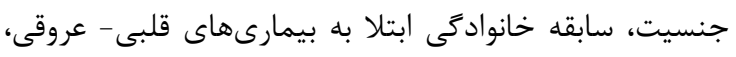

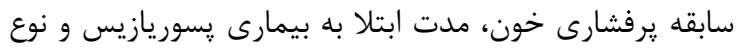

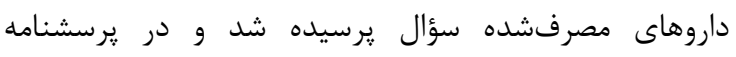

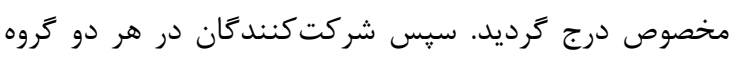

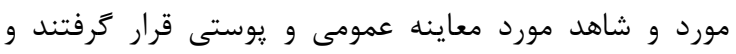

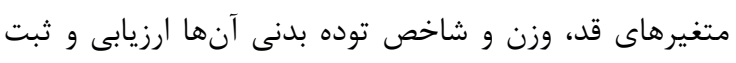

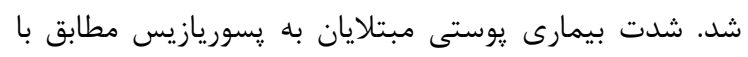
فرمول PASI مندرج در شكل ا محاسبه كرديد. در اين معيار
يوسجولار و اريترودرميك از انواع بالينى ديخر اين بيمارى هستند

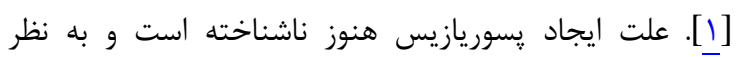
مىرسد كه يك عامل وراثتى مولتىفاكتوريال در آن نقش دارد.

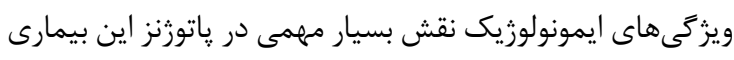
دارند. يسوريازيس يكى بيمارى وابسته بـ T-cell

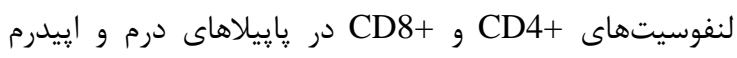

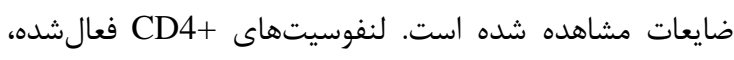

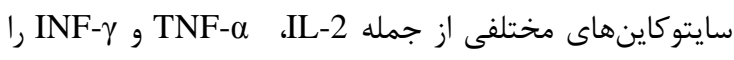
توليد مى كنند؛ هرجند كه اين سايتوكاينها توسط لنفي إنفوسيت

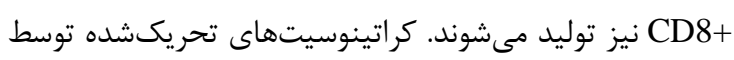

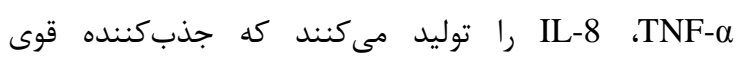
لنفوسيتهاى T و نوتروفيلها مىباشد [ب].

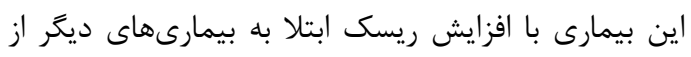

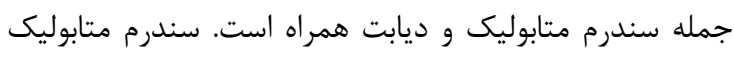
تركيبى از ريسكفاكتورهاى كارديووسكولار شامل: مقاومت به

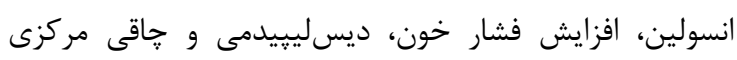

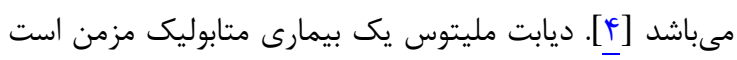

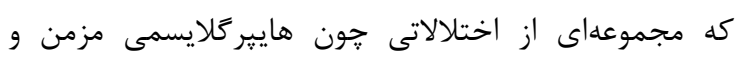

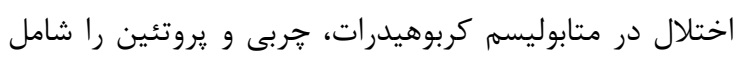

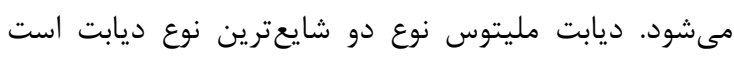

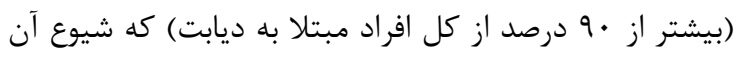

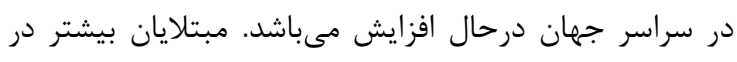

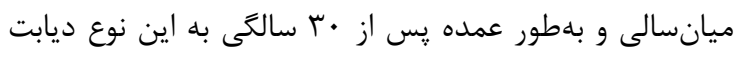

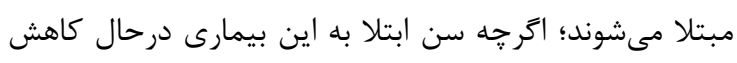

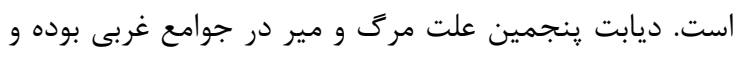

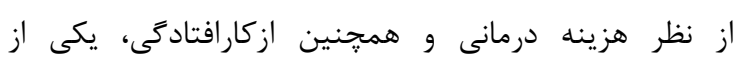

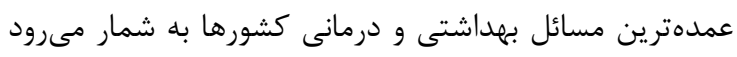

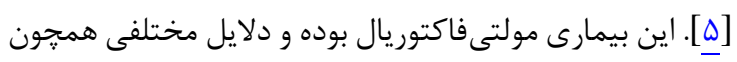

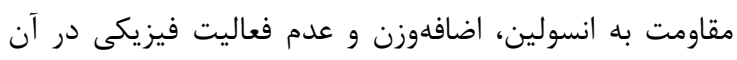

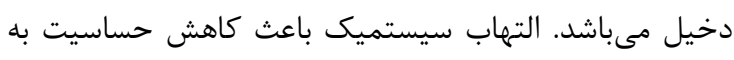

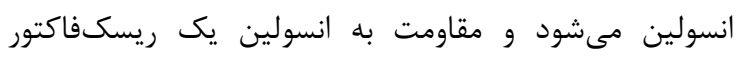

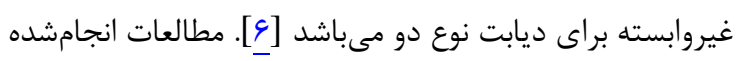

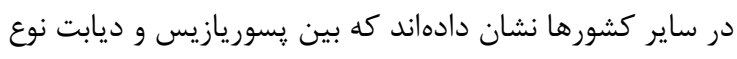

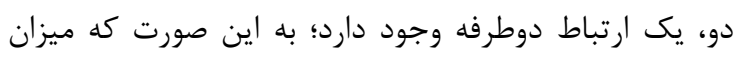

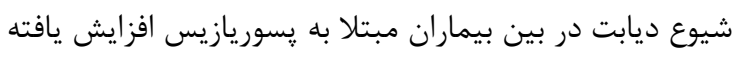

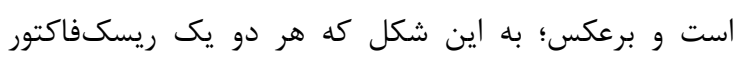

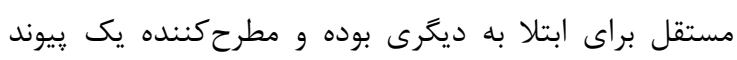

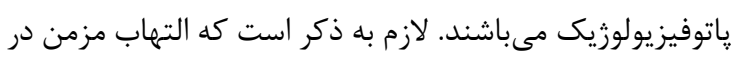

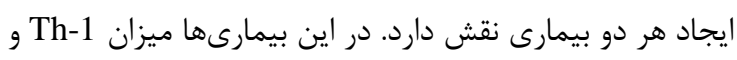

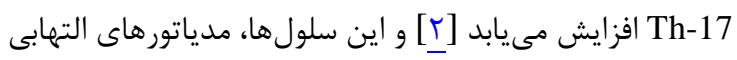

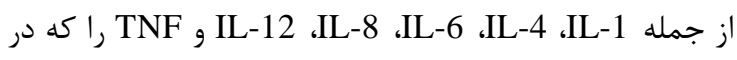

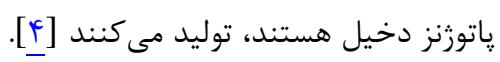
براساس مطالعات انجامشده و مكانيسمهاى مشترك ايمونولوزيك دئن

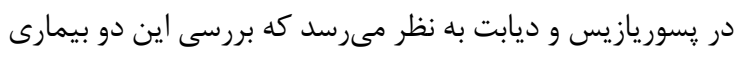




\begin{tabular}{|c|c|c|c|c|}
\hline \multicolumn{5}{|c|}{ CALCULATION OF THE PSORIASIS AREA AND SEVERITY INDEX (PASI) } \\
\hline \multicolumn{5}{|c|}{ Severity of psoriatic lesions [ 0 , none; 1 , slight; 2 , moderate; 3 , severe; 4 , very severe] } \\
\hline & Head & Trunk & Upper limbs & Lower limbs \\
\hline Erythema & 0 to 4 & 0 to 4 & 0 to 4 & 0 to 4 \\
\hline Induration & 0 to 4 & 0 to 4 & 0 to 4 & 0 to 4 \\
\hline Scaling & 0 to 4 & 0 to 4 & 0 to 4 & 0 to 4 \\
\hline Total score $=1$ & Sum of the above & Sum of the above & Sum of the above & Sum of the above \\
\hline \multicolumn{5}{|c|}{$\begin{array}{l}\text { Area of psoriatic involvement }[0, \text { none; } 1,<10 \% ; 2,10 \text { to }<30 \% ; 3,30 \text { to }<50 \% ; 4,50 \text { to }<70 \% ; 5,70 \text { to }<90 \% \text {; } \\
6,90-100 \%]\end{array}$} \\
\hline $\begin{array}{l}\text { Degree of } \\
\text { involvement }=\mathbf{2}\end{array}$ & 0 to 6 & 0 to 6 & 0 to 6 & 0 to 6 \\
\hline Multiply $\mathbf{1} \times \mathbf{2}$ & $1 \times 2$ & $1 \times 2$ & $1 \times 2$ & $1 \times 2$ \\
\hline $\begin{array}{l}\text { Correction factor for } \\
\text { area of involvement }=3\end{array}$ & 0.10 & 0.30 & 0.20 & 0.40 \\
\hline $1 \times 2 \times 3$ & A & B & C & D \\
\hline \multicolumn{5}{|c|}{$\mathbf{A}+\mathbf{B}+\mathbf{C}+\mathbf{D}=$ total PASI } \\
\hline
\end{tabular}

شكل ا: ايندكس محاسبه شدت بيمارى يوستى مبتلايان به پِوريازيس (PASI)

صورت برقراربودن شرايط كوكران از آزمون مجذور كاى و در

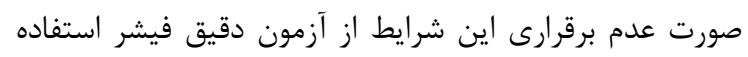

\section{يافته ها}

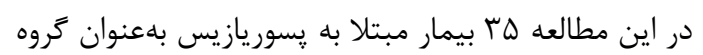

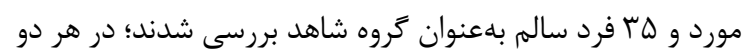

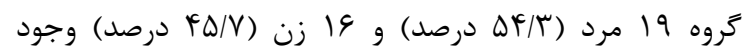

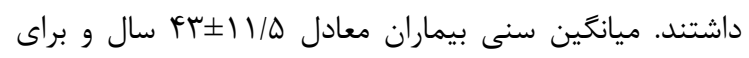

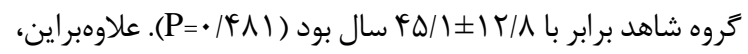

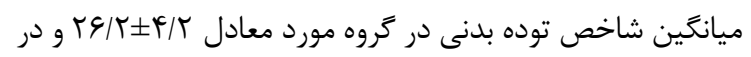

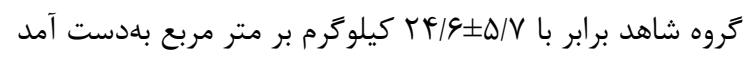

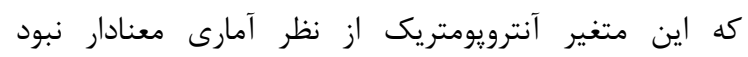
(P=•//VA)

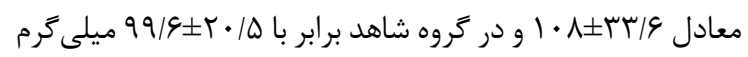

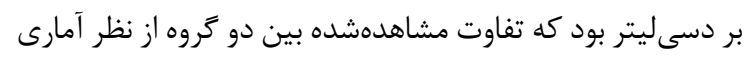

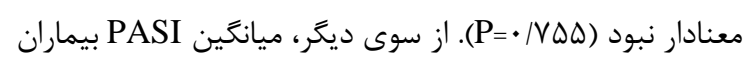

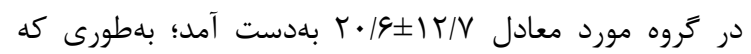

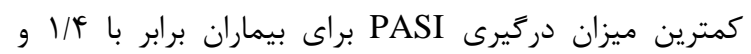

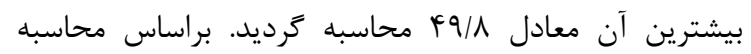
PASI

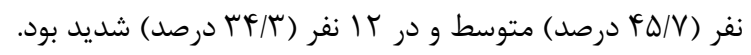

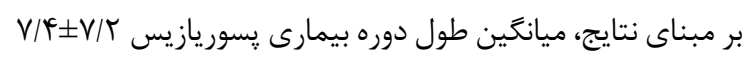

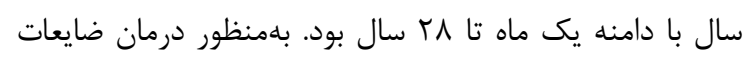

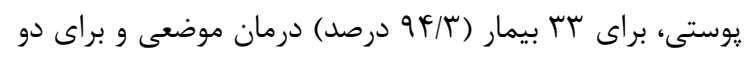

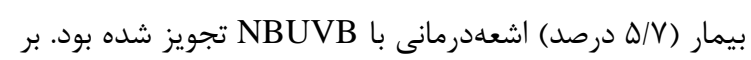

براساس تخمين وسعت بيمارى (درصد درگيرى يوست)، شدت

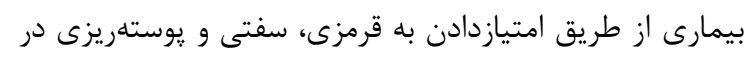

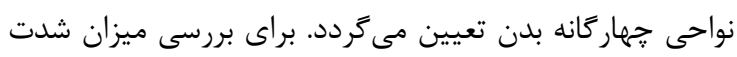

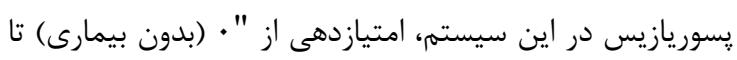

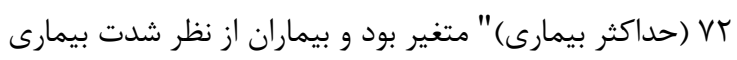

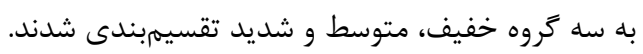

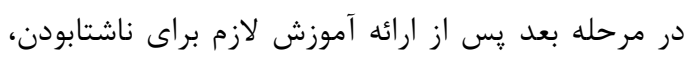

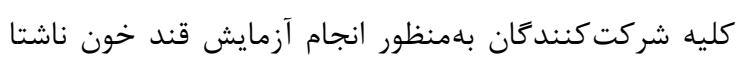

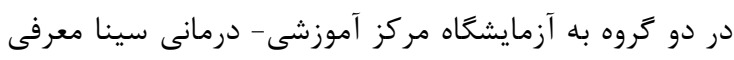

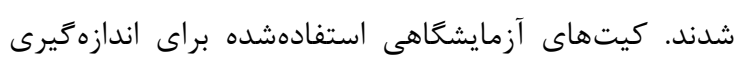

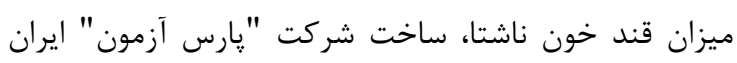

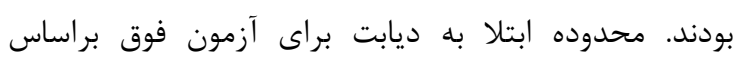

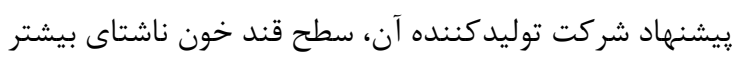

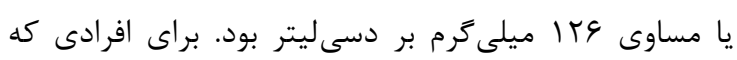

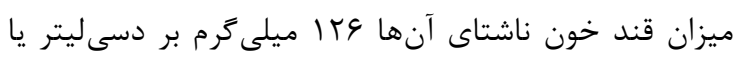

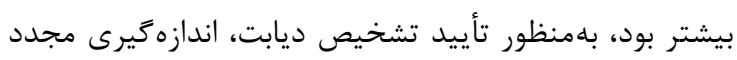
قند خون ناشتا انجام شد.

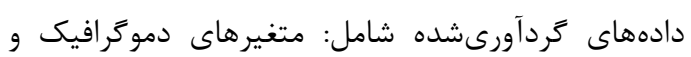

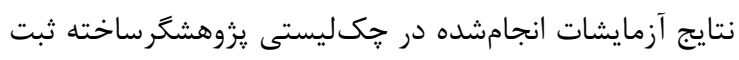

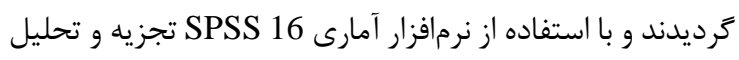

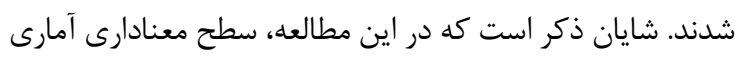

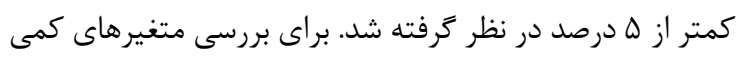

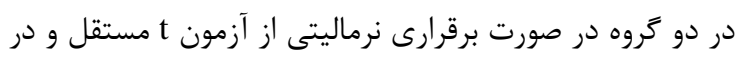

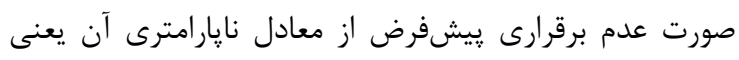

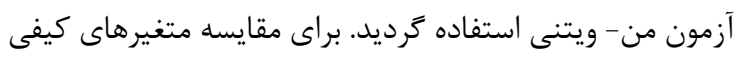

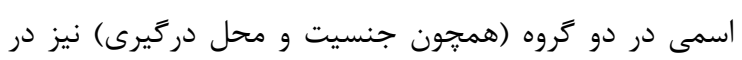


نمىباشد. علاوهبراين، در بررسى توزيع فراوانى ديابت در

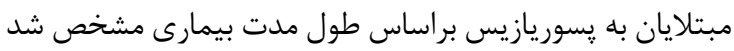

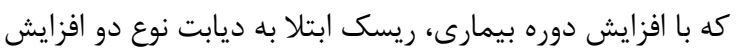

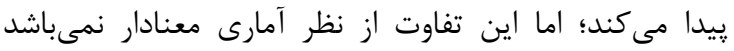
(P=•/VAr)

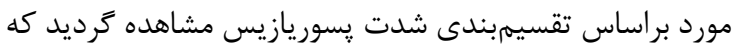

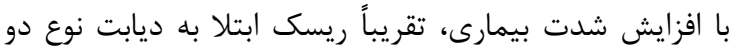

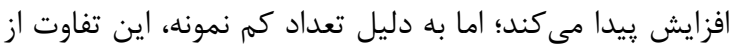

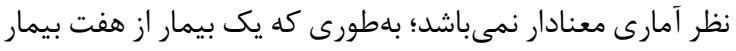

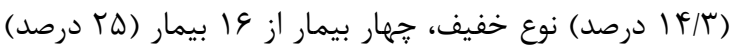

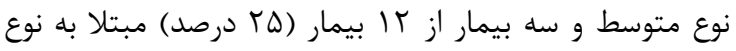

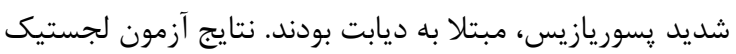

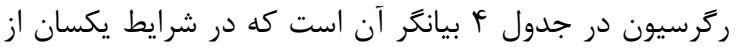

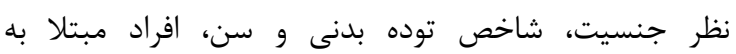

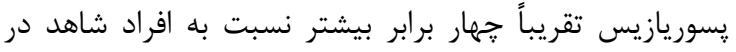

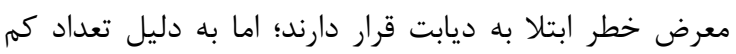

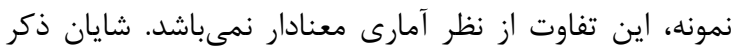

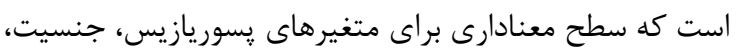

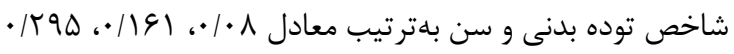

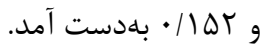

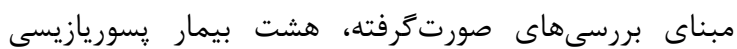

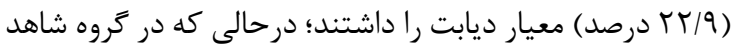

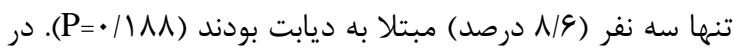

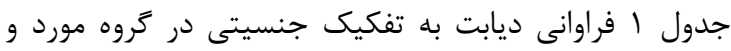

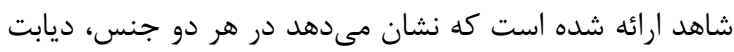

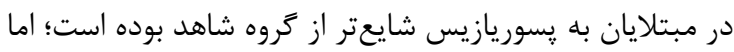

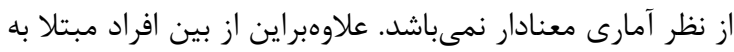

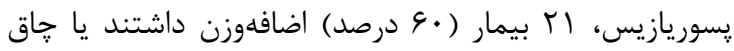

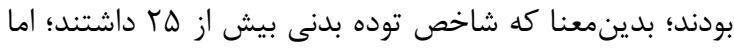

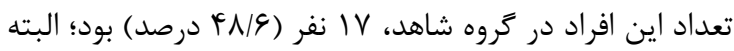
تفاوت مشاهدهشه بين دو گروه از نظر آمارى معنادار نبود

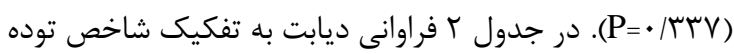

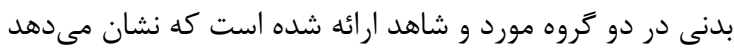

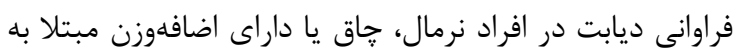

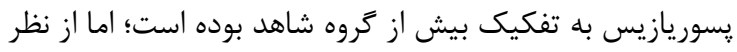

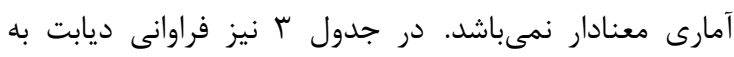

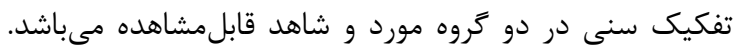

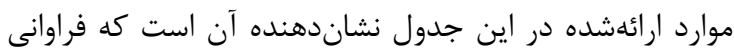

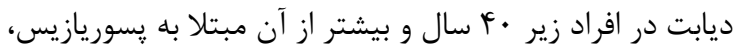

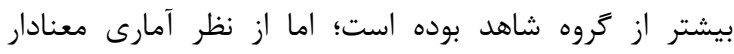

جدول ا: مقايسه فراوانى ديابت در گروه مورد و شاهد به تفكيك جنسيت

\begin{tabular}{|c|c|c|c|c|c|c|}
\hline \multicolumn{3}{|c|}{ زن } & \multicolumn{3}{|c|}{ مرد } & \multirow[b]{2}{*}{ ابتلا به ديابت } \\
\hline معنادارى سطح & فراوانى (درصد) & فراوانى (درصد) & معنادارى سطح & فراوانى (درصد) & فراوانى (درصد) & \\
\hline \multirow{3}{*}{$1 / \cdot \cdot$} & $(V Q) \backslash T$ & $(\Lambda 1 / r) \| r$ & \multirow{3}{*}{$\cdot 11 \cdot 0$} & $(\vee \wedge / Q) \backslash Q$ & $(1 \cdots) 19$ & خير \\
\hline & $(r \Delta) F^{F}$ & $(\mid \Lambda / \Lambda) \Gamma$ & & $(Y / /) Y$ & $\cdot$ & بله \\
\hline & $(1 \cdots) 19$ & $(1 \cdots) 19$ & & $(1 \cdots) 19$ & $(1 \cdots) 19$ & مجموع \\
\hline
\end{tabular}

جدول r: مقايسه فراوانى ديابت در كروه مورد و شاهد به تفكيك شاخص توده بدنى

\begin{tabular}{|c|c|c|c|c|c|c|}
\hline \multicolumn{3}{|c|}{ جاق يا داراى اضافهوزن (BMI>rA) } & \multicolumn{3}{|c|}{ 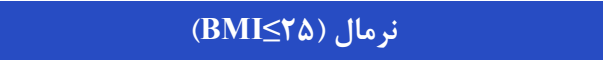 } & \multirow[b]{2}{*}{ ابتلا به ديابت } \\
\hline معنادارى سطح & فراوانى (درصد) & فراوانى (درصد) شاهد & معنادارى سطح & فراوانى (درصد) & فراوانى (درصد) & \\
\hline \multirow{3}{*}{$1 / \cdot$} & $(\wedge \Delta / \vee) \backslash \Lambda$ & $(\Lambda \Lambda / T) \backslash \Delta$ & \multirow{3}{*}{$\cdot 1 \cdot 9$} & $(\Phi \& / \Psi) q$ & $(q F / F) I V$ & خير \\
\hline & $(\mid F / \Gamma) r$ & $(1) / \Lambda) r$ & & $(r \Delta / V) \Delta$ & $(\Delta / 9) 1$ & بله \\
\hline & $(1 \cdots) Y I$ & $(1 \cdots) I V$ & & $(1 \cdot \cdot) \mid f$ & $(1 \cdots) 11$ & مجموع \\
\hline
\end{tabular}

جدول ץ: مقايسه فراوانى ديابت در تروه مورد و شاهد به تفكيك تروه سنى

\begin{tabular}{|c|c|c|c|c|c|c|}
\hline معنادارى سطح & فش از • مراوانى (درصد) & فراوانى (درصد) & معنادارى سطح & 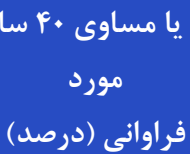 & 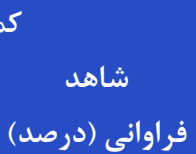 & ابتلا به ديابت \\
\hline \multirow{3}{*}{$\cdot / T \Delta V$} & $(\varepsilon \wedge / \mathcal{F}) \|$ & $(\Lambda \vee) Y$. & \multirow{3}{*}{ - /4qr } & $(\wedge \vee / \Delta) \backslash \mathcal{F}$ & $(1 \cdot) \mid r$ & خير \\
\hline & $(r \mid / 9)^{4}$ & r & & $(1 T / \Delta) r$ & - & بله \\
\hline & $(1 \cdots) 19$ & r & & $(1 \cdots) 19$ & r & مجموع \\
\hline
\end{tabular}


جدول f: مدل ركرسيون لجستيك براى شناسايى عوامل تعيين كننده بروز ديابت

\begin{tabular}{|c|c|c|c|}
\hline فاصله اطمينان ه9 درصد & سطح معنادارى & نسبت شانس (OR) & متغير \\
\hline$\cdot \mid \wedge r-19 / 9$ & $\cdot / \cdot 1$ & $r / \Lambda$ & يسوريازيس \\
\hline$\cdot 199-11 / 4$ &.$|19|$ & $T / V$ & جنسيت (زن) \\
\hline$\cdot / \vee \wedge-1 / \cdot 1$ & $\cdot / 490$ & $\cdot 194$ & شاخص توده بدنى \\
\hline$\cdot / 91-1 / 11$ & $\cdot / 1 \Delta T$ & $1 / \cdot 1$ & سن \\
\hline
\end{tabular}

سندروم متابوليك و هاييركليسمى مىباشند [l[1]]. كوهن و

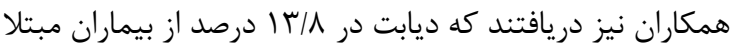

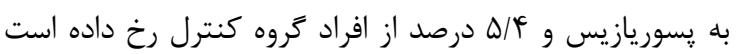

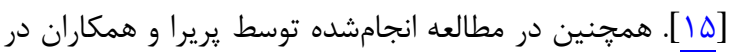

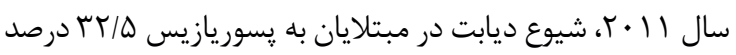

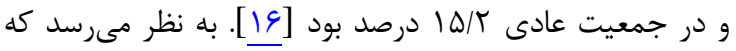

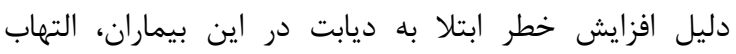

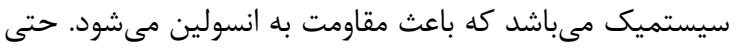

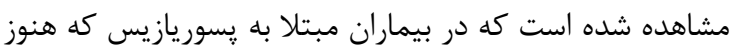
ديابت در آنها تشخيص داده نشده است، مقاومت بـد اسه انسولين وجود دارد [IV] از سوى ديگر، در اين مطالعه شاخص توده بدنى در دو تروه

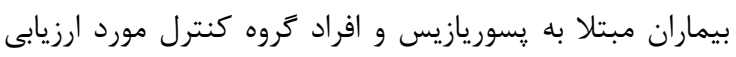

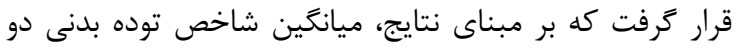

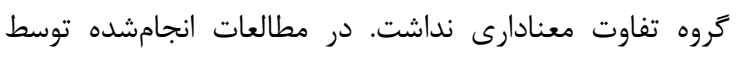

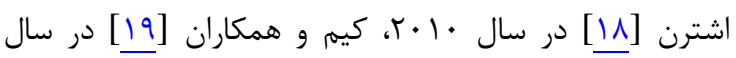

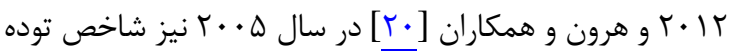

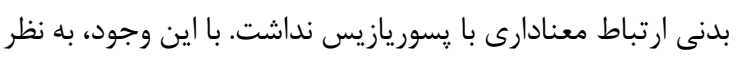

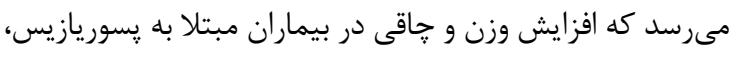

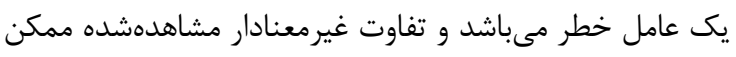

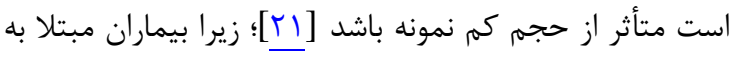

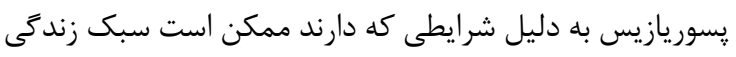

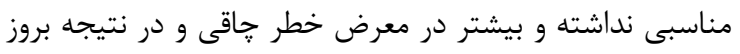

ديابت قرار داشته باشند [Tr].

\section{نتيجه كيرى}

ابتلاى همزمان به يسوريازيس و ديابت، كيفيت زندگى فرد

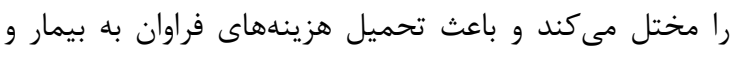

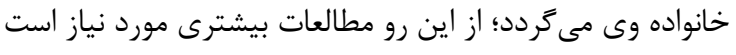

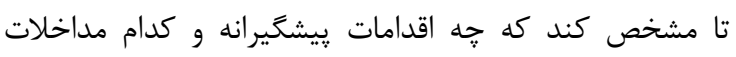
درمانى مىتوانند در بهبود اين بيماران و كنترل ييامدهاى بيمارى

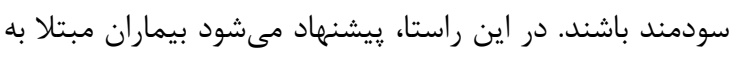

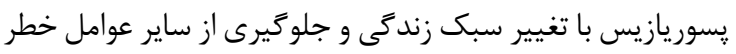

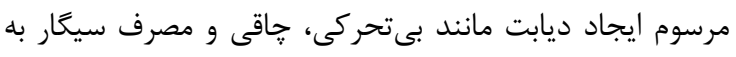
مراقبت بهتر از خود بيردازند. علاوهبراين، از آنجايى كه بهابت بالابودن

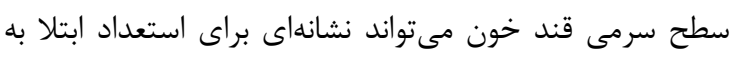

يسوريازيس يكى از شايعترين بيمارىهاى يوستى است كه

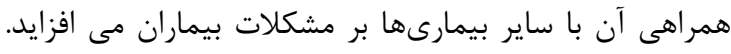

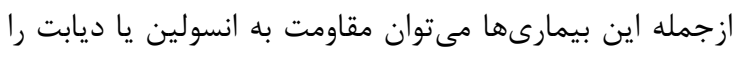

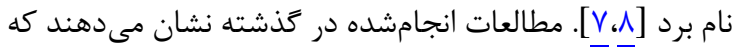

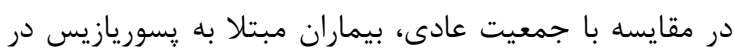

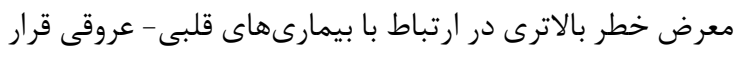

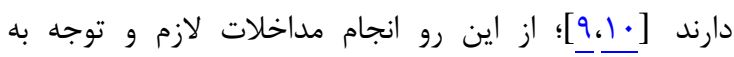

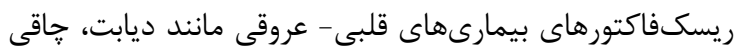

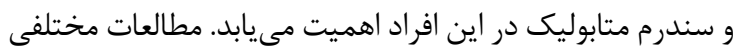

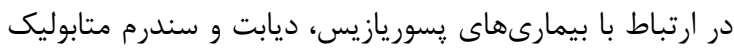

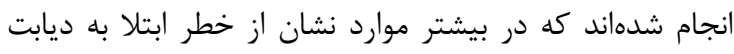

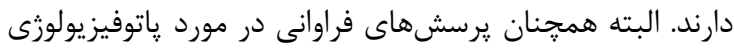

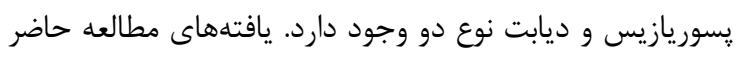

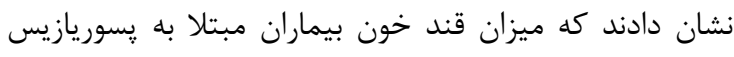

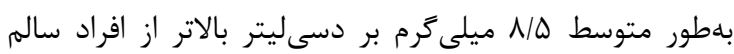

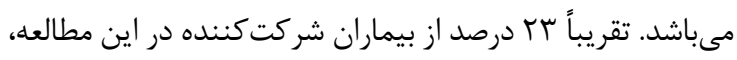

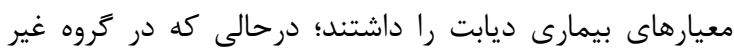

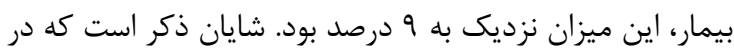

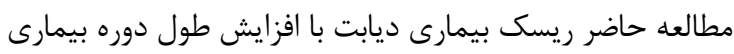
و شدت يسوريازيس افزايش يافت كه از نظر آمارى معنادار نبود.

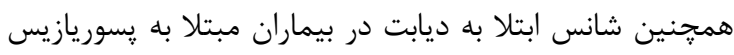
تقريباً جهار برابر افراد غير بيمار بود.

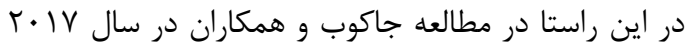

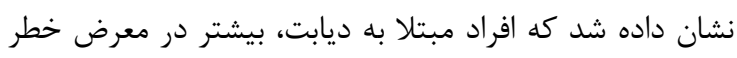

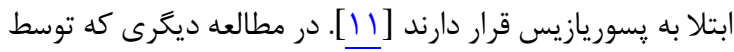

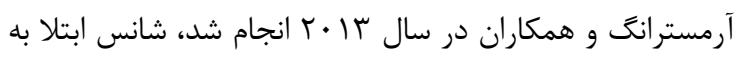

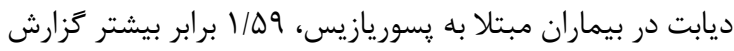

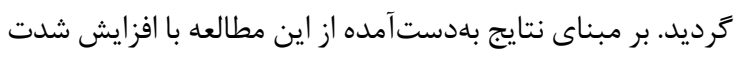

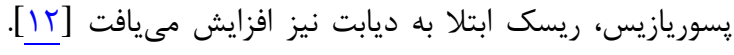

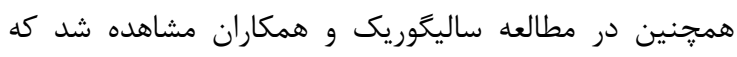
افزايش PASI و خطر سندرم متابوليك در بيماران مبتلا به

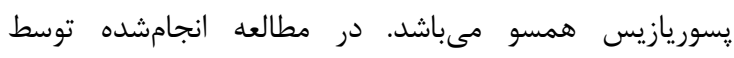

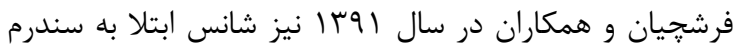

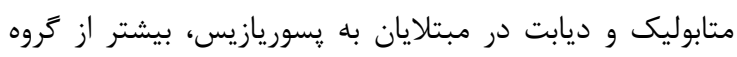

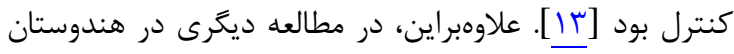

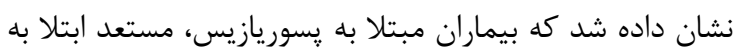


تضاد منافع

نتايج اين مطالعه با منافع نويسندكان در تعارض نمىباشد.

ملاحظات اخلاقى

مطالعه حاضر داراى تأييديه اخلاق در يزوهش با كد

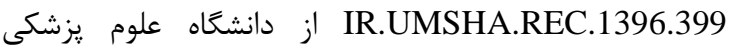
همدان مىباشد.

سمهم ذويسنلف

نويسنده اول (نويسنده مسئول): يروهشكر اصلى، نحارش

بخشهاى مقدمه، روششناسى، نتايج، بحث مقاله ( • م درصد)؛

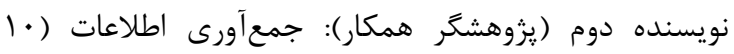

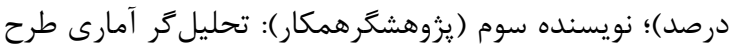

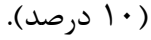

حمايت مالى

مطالعه حاضر از سوى هيج سازمان يا اركانى يشتيبانى مالى لئ

نشده است.

\section{REFERENCES}

1. Menter A, Gottlieb CA, Feldman SR, Van Voorhees AS, Leonardi CL, Gordon KB, et al. Guidelines of care for the management of psoriasis and psoriatic arthritis: Section 1. Overview of psoriasis and guidelines of care for the treatment of psoriasis with biologics. J Am Acad Dermatol. 2008; 58(5):826-50. PMID: 18423260 DOI: $10.1016 /$ j.jaad.2008. $\underline{02.039}$

2. Schwandt A, Bergis D, Dappa A, Ebner S, Jehle PM, Koppen S. Psoriasis and diabetes: A multicenter study in 222078 type 2 diabetes patients reveals high levels of depression. $J$ Diabetes Res. 2015;2015:792968. PMID: 26357664 DOI: $10.1155 / 2015 / 792968$

3. Elder DE. Histopathology of the skin. $10^{\text {th }}$ ed. Philadelphia: Lippincott Williams and Wilkins; 2009. P. 174.

4. Salihbegoric EM, Hadzigrahic N, Cickusic AJ. Psoriasis and metabolic syndrome. Med Arch. 2015;69(2):85-7. PMID: 26005254 DOI: 10.5455/medarh.2015.69.85-87

5. Kasper D, Fauci A, Hauser S, Longo D, Jameson J, Loscalzo J. Harrison's principles of internal medicine. New York: McGraw-Hill Professional Publishing; 2012. P. 3003.

6. Gyldenlove M, Storgaard H, Holst JJ, Vilsboll T, Knope FK, Skov L. Patients with psoriasis are insulin resistant. J Am Acad Dermatol. 2015;72(4):599-605. PMID: 25653028 DOI: 10.1016/j.jaad.2015.01.004

7. Baeta IG, Bittencourt FV, Gontijo B, Goulart EM. Comorbidities and cardiovascular risk factors in patients with psoriasis. An Bras Dermatol. 2014;89(5):735-44. PMID: 25184912 DOI: $10.1590 / \mathrm{abd} 1806-4841.20142874$

8. Al-Mutairi N, Al-Farag S, Al-Mutairi A, Al-Shiltawy M. Comorbidities associated with psoriasis: an experience from the Middle East. J Dermatol. 2010;37(2):146-55. PMID: 20175849 DOI: 10.1111/j.1346-8138.2009.00777.x

9. Husted JA, Thavaneswaran A, Chandran V, Eder L, Rosen $\mathrm{CF}$, Cook RJ, et al. Cardiovascular and other comorbidities in patients with psoriatic arthritis: a comparison with patients with psoriasis. Arthritis Care Res (Hoboken). 2011; 63(12):1729-35. PMID: 21905258 DOI: 10.1002/acr.20627

10. Kimball AB, Robinson D Jr, Wu Y, Guzzo C, Yeilding N, Paramore $\mathrm{C}$, et al. Cardiovascular disease and risk factors among psoriasis patients in two US healthcare databases, 2001-2002. Dermatology. 2008;217(1):27-37. PMID: 18349542 DOI: $10.1159 / 000121333$

11. Jakob L, Kostev K. Psoriasis risk in patients with type 2
ديابت در اين بيماران باشد، انجام غربالخرى در ارتباط با ديابت نوع دو در بيماران يسوريازيس منطقى به نظر مىرسد. اين تدابير

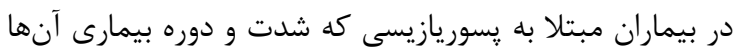
بيشتر است، ضرورت بيشترى دارد؛ بنابراين با توجه به ماهيت بيمارى ديابت نوع دو كه با افزايش خطر بيمارىهاى قلبى عروقى همراه است، يزشكان همواره بايد اين عامل خطر را در نظر داشته باشند تا با كنترل مناسب قند خون از عوارض و مرگ و مير ناشى از بيمارىهاى قلبى- عروقى در بيمارانى كه همزمان به ديابت و يسوريازيس مبتلا هستند، جلوگيرى نمايند و كيفيت زندگى آنها را ارتقا بخشند.

$$
\text { تشعر و قنروازى }
$$

مقاله حاضر برگرفته از ياياننامه دوره دكترى حرفهاى يزشكى مصوب دانشگاه علوم پيزشكى همدان به شماره

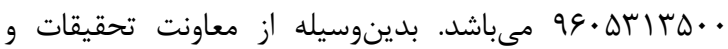
فناورى دانشخاه و تمامى افرادى كه در مراحل اجرايى، تصويب يرويوزال و گردآورى دادهها نويسند

$$
\text { تشكر و قدردانى مى }
$$

diabetes in German primary care practices. Prime Care Diabetes. 2017;11(1):52-6. PMID: 27460887 DOI: 10.1016/ j.pcd.2016.07.002

12. Armstrong AW, Harskamp CT, Armstrong EJ. Psoriasis and metabolic syndrome: a systemic review and meta-analysis of observational studies. J Am Acad Dermatol. 2013;68(4):65462. DOI: 10.1016/j.jaad.2012.08.015

13. Farshchian M, Ansar A, Sobhan MR, Torabian S. Psoriasis and risk factors of metabolic syndrome: A case-control study. Dermatol Cosmet. 2013;4(1):10-8.

14. Nisa N, Qasi MA. Prevalence of metabolic syndrome in patients with psoriasis. Indian J Dermatol Venerol Leprol. 2010;76(6):662-5. DOI: 10.4103/0378-6323.72462

15. Cohen AD1, Dreiher J, Shapiro Y, Vidavsky L, Vardy DA, Davidovici B, et al. Psoriasis and diabetes: a populationbased cross-sectional study. J Eur Acad Dermatol Venerol. 2008;22:585-9. PMID: 18331320 DOI: 10.1111/j.14683083.2008.02636.x

16. Pereira RR, Amladi ST, Varthakavi PK. A study of the prevalence of diabetes, insulin resistance, lipid abnormalities and cardiovascular risk factors in patients with chronic plaque psoriasis. Indian J Dermatol. 2011;56(5):520-6. PMID: 22121269 DOI: 10.4103/0019-5154.87144

17. Shalom G, Shapiro J, Dreiher J, Nathan A, Freud T, Comaneshter D, et al. Glycemic control in patients with diabetes and concomitant psoriasis. Br J Dermatol. 2016; 175(2):428-30. PMID: 26991639 DOI: $10.1111 /$ bjd.14545

18. Stern RS. Psoriasis is not a useful independent risk factor for cardiovascular disease. J Invest Dermatol. 2010;130(4):9179. PMID: 20231828 DOI: $10.1038 /$ jid.2009.446

19. Kim GW, Park HJ, Kim HS, Kim SH, Ko HC, Kim BS, et al. Analysis of cardiovascular risk factors and metabolic syndrome in Korean patients with psoriasis. Ann Dermatol. 2012;24(1):11-5. PMID: 22363149 DOI: 10.5021/ad.2012. 24.1.11

20. Herron MD, Hinckley M, Hoffman MS, Papenfuss J, Hansen $\mathrm{CB}$, Callis KP, et al. Impact of obesity and smoking on psoriasis presentation and management. Arch Dermatol. 2005;141(12):1527-34. PMID: 16365253 DOI: 10.1001/ archderm.141.12.1527

21. Lønnberg AS, Skov L, Skytthe A, Kyvik KO, Pedersen OB, Thomsen SF. Association of psoriasis with the risk for type 2 diabetes mellitus and obesity. J Am Acad Dermatol. 
2016;152(7):761-7. PMID: 27120802 DOI: 10.1001/ jamadermatol.2015.6262

22. Kothiwala SK, Khanna N, Tandon N, Naik N, Sharma VK, Sharma S, et al. Prevalence of metabolic syndrome and cardiovascular changes in patients with chronic plaque psoriasis and their correlation with disease severity: a hospital- based cross- sectional study. Indian J Dermatol Venerol Leprol. 2016;82(5):510-8. PMID: 27297282 DOI: $\underline{10.4103 / 0378-6323.183638}$ 